\title{
БУРЯ ВАСИЛЯ ТКАЧУКА (ПРО ЗАБУТУ НОВЕЛУ “ЗАГУБЛЕНОГО ТАЛАНТУ”)
}

\author{
АННА ГОРНЯТКО-ШУМИЛОВИЧ \\ Університет імені Адама Міцкевича, Познань - Польща \\ anna.horniatko@wp.pl \\ BURZA WASYLA TKACZUKA \\ (O ZAPOMNIANEJ NOWELI “ZAGUBIONEGO TALENTU”) \\ ANNA HORNIATKO-SZUMIŁOWICZ \\ Uniwersytet imienia Adama Mickiewicza, Poznań — Polska
}

STRESZCZENIE. Artykuł omawia motyw burzy w noweli Wasyla Tkaczuka pod tym samym tytułem. Dowiedziono, iż burza symbolizuje nie tylko żywioł, lecz również ludzkie emocje. W. Tkaczuk po mistrzowsku oddaje charakter żywiołu, porównywanego ze światem wewnętrznym bohaterów za pomocą różnorodnych środków stylistycznych.

\section{VASIL TKACHUK'S TEMPEST (ABOUT A FORGOTTEN NOVELLA “LOST TALENT”)}

\author{
ANNA HORNIATKO-SZUMIŁOWICZ \\ Adam Mickiewicz University, Poznan — Poland
}

ABSTRACT. The article focuses on the discussion of the motif of tempest in Vasil Tkachuk's novella under the same title. It is doubtless that the tempest symbolizes not only the force of the nature, but also the human emotions. V. Tkachuk masterfully captures the essence of a raging thunderstorm, which is being compared with an internal world of the characters with the use of various stylistic means.

$\Pi$ опри традиційну “селеписність”, “стефаниківські рецидиви” й загалом невеликі за обсягом літературні здобутки (чотири збірки малої прози) Василь Ткачук - "загублений талант" залишив після себе віртуозні новели. Поміж унікальної прозової спадщини особливо захоплює один з його забутих шедеврів - Буря.

\footnotetext{
${ }^{1}$ Василь Ткачук народився в 1916 р. в селі Іллінці на Покутті в селянській сім’ї. Його, брата Олексія і сестру Марію виховувала мати. Батько помер 1921 р. Василь виявився обдарованою дитиною, його перші літературні спроби випали на шкільні роки. Дебютну новелу Великдень іде Ткачук опублікував 1933 р. в журналі „Жіноча доля”. 1934 року письменник переїхав у Львів, де став членом літературного угрупування „Дванадцятка”. 1937 р. він одружився з Марією Януш. Через рік народилася єдина донька новеліста Ольга, яка досі живе в Щецині в Польщі. Дедалі популярнішого Василя Ткачука захопило міське життя, він покинув сім'ю. Водночас почав 3 великим успіхом публікувати збірки новел. За життя письменника вийшли чотири його книжки: Сині чічки (1935), Золоті дзвінки (1936), Зимова мелодія (1938), Весна (1940). 1941 р. його призвали до лав Радянської армії. Загинув, імовірно, в 1944 році.

Радянська історіографія навмисне забула про творчість галицького новеліста. Він сам попав під цензуру й лише в 1973 році опублікували його невелику збірку Новели (1973). У наш час старанням дочки письменника Ольги Гоффманн вийшли дві збірки новеліста - Сині чічки (2013) і Золоті дзвінки (2014). Процес його “повернення із забуття” здійснюється поволі, протягом кільканадцяти останніх років і ще не завершений. Прикметно, що новеліст викликав величезне зацікавлення своєю творчістю поміж українських критиків $30-$-х років XX ст.
} 
Мотив бурі широко репрезентований в українській літературі. Уже в народній думі Буря на Чорному морі шалена морська громовиця стає символом гріхопадіння козаків і їхнього порятункуㄹ․ У першій українській новелі Сатир Самійла Величка демонський збір супроводжується шаленою бурею³. До мотиву раптової бурі звертається зачинатель художньої прози в українській літературі Григорій Квітка-Основ'яненко. У його Перекотиполі (1840), що ваважається першим оповіданням з елементами психологізму, генологія злочину розкрита за допомогою заголовного перекотиполя. Раніше злочинець зі страху перед

Про його творчу манеру схвально відгукувались тодішні літературознавці та критики, зокрема Михайло Рудницький, Мирослав Семчишин, Микола Голубець, Остап Грицай, Григор Лужницький (Л. Нигрицький), Іван Огієнко, Ірина Вільде та ін. 3-поміж сучасних дослідників увагу письменницькій спадщині В. Ткачука приділяли різною мірою Тарас Мигаль, Володимир Лучук, Ярослав Дорошенко, Володимир Морозюк, Роман Горак, Степан Хороб, Христина Федор, Христина Синітович та ін.

За відновлення та збереження пам'яті про Ткачука-новеліста боролись Роман Ризюк і дочка Ольга Гоффманн. Див., напр.: М. Рудницький, Сільський хлопчина дивиться на світ, [в:] „Діло” 1935, 19 лист.; М. Рудн иць к й , Василь Ткачук „Весна”, [в:] „Література і мистецтво” 1940, № 1, с. 14-22; М.Семчи ши н, Село в нарисах Василя Ткачука, [в:] „Наш прапор” 1935, 17 жовт.; М. Голубець, Дебют новеліста, [в:] „Новий час” 1935, 10 лист.; О. Грицай, Цікавий дебют, [в:] „Свобода” 1936, № 109; Л. Нигрицький, Передмова (друкується за виданням з 1935), [в:] В. Ткачук, Золоті дзвінки, підготовка текстів, упоряд. та післяслово Р. Гор ака, Львів 2014, с. 5-6; I. Огієн ко, Василь Ткачук: „Зимова мелодія”, [в:] „Рідна мова” 1939, ч. 3, с. 139-140; І. В іль де, Василь Ткачук: „Золоті дзвінки”, [в:] Ї̈ї ж, Незбагненне серие, упорядкув., вст. стаття Забутий світ Ірини Вільде і прим. М.А.В ель о, Львів 1990, с. 14-18; I. В іль де , Гість у нашій редакиії, [в:] Ї̈̈ ж, Незбагненне серие, упорядкув., вст. стаття Забутий світ Ірини Вільде і прим. М. А. В ель о, Львів 1990, с. 11-13; Т. Мигаль, Ми не забули тебе, легінику, [в:] „Літературна Україна” 1965, 8 черв.; В. Лучук, Письменник-демократ, [в:] В. Ткачук, Новели, Львів 1973, с. 3-8; Я. Дорошен ко, Ім'я відновив ювілей, [в:] „Галичина” 1991, 30 січ.; В. Мор оз юк, Золоті дзвінки Василя Ткачука, [в:] „Галичина” 2001, 13 вер., с. 10; C. I. Хороб, Один із когорти учнів славетного новеліста (Прозова творчість В. Ткачука), [в:] „Вісн. Дніпропетров. ун-ту ім. Альфреда Нобеля. Сер. Філологічні науки”, Дніпропетровськ 2013, № 2 (6), с. 222-228; Х. Федор, Василь Ткачук в західноукраӥнському літературному та культурному процесі початку XX століття, [в:] „Гуманітарна освіта в технічних вищих навчальних закладах", зб. наук. праць, Київ 2013, № 29, с. 260-278; Х. Фе до р, Василь Ткачук крізь призму розгортання ним стефаниківських традицій, [в:] „Гуманітарна освіта в технічних вищих навчальних закладах”, зб. наук. праць, Київ 2015, № 31, с. 231-243; Х. Федор, Колористика творів Василя Ткачука та ї̈ роль у висвітленні ідейно-художніх домінант прози письменника, [в:] „Гуманітарна освіта в технічних вищих навчальних закладах”, зб. наук. праць, Київ 2014, № 30, с. 235-243; Х. Син і то в ич, Життєвий і творчий шилях Василя Ткачука, [в:] В. Ткачук, Сині чічки. Новели, Івано-Франківськ 2013, с. 5-13; Р. Гор ак, Загублений талант Василя Ткачука, [в:] В. Ткачук, Золоті дзвінки, підготовка текстів, упоряд. та післяслово Р. Горака, Львів 2014, с. 239-303; Р. Горак, Василь Ткачук з Ілліниів, [в:] „Перевал” 2015, ч. 3-4, с. 294-304; О. Гоффманн, До сторіччя з дня народження Василя Ткачука - спогади дочки письменника, [в:] „Almanach Ukraiński 2016”, pod red. R. Kramara, Warszawa 2016, c. 260-270; О.Гоффманн, Хто такий Василь Ткачук. До сто-річчя з дні народження, [в:] „Наше Слово” 2016, 17 січ., с. 10.

${ }^{2}$ Ізо дна моря сильна хвиля вставає, / Судна козаџькі молодецькі на три часті розбиває. [...] / То як стали словами промовляти, / Отиеву і матчину молитву споминати, - / Став Господь милосердний їм помагати, / Стало Чорне море утихати. Див.: Українські народні думи та історичні пісні. Збірник, упоряд. та прим. О. Таланчук, передм. Б. Кирдан а, Київ 1990, c. $91,93$.

${ }^{3}$ А коли йому відразу його принесли, повелів він затрубити в нього. Коли ж був посланий бридко гаркітливий голос того рогу, тоді всі недоборські дерева захиталися і моє зі мною мало не впало. Була відразу після того по всьому Недобору велика буря, шум, невимовне сум'яття i вихори, від яких всі звірі побігли й полетіли з великим поспіхом геть з Недобора [...]. Див.: С.Величко, Сатир, [в:] Ю.Виннничук, Чорт зна щъо, зазнач. джер., с. 68. 
буряною стихією зізнається товаришу у скоєнні багатьох злочинів ${ }^{4}$. До мотиву бурі (інколи зимової хурделиці) охоче звертались українські романтики у своїх фантастичних розповідях про відьом, чортів, упирів, вовкулак тощо, зокрема Орест Сомов (Київські відьми $)$, Володимир Росковшенко (Орендатор $\left.{ }^{6}\right)$ чи Пателеймон Куліш (Огненний змій, 1840). Останній включає мотив бурі в бувальщину, що іiі розповідав Іван Костюченко на воронезьких вечорницях (про те, як „великий пан $з$ ляхів” запродав душу дияволу ${ }^{7}$ ). Так само й “запізнений романтик” Олекса Стороженко у Марку Проклятому (1870) згадує бурю, що супроводила злодіяння заголовного Марка ${ }^{8}$. Як правило, романтики змальовували природу в момент стихії, грози, повені, бурі, урагану, що допомагало їм розкрити незвичайність романтичного героя. Описом бурі, що настроює читача на щось грізне, трагічне, починається Причинна (1837) Тараса Шевченка9 й типологічно споріднена з нею Молодиия (1828) першого українського романтика Левка Боровиковського ${ }^{10}$. Так само і в першоповісті Івана Франка Петрії $i$ Довбущуки (1875) настрій таємничості підсилений описом гірського буревію ${ }^{11}$. У романі Повія $(1883-1884,1928)$ Панаса Мирного розгорнутий мотив бурі, що одночасно шаленіс надворі у вигдяді завірюхи зимовою порою і в понівеченій душі Пріськи ${ }^{12}$. У супроводі зловіщого передгроззя “Я герой” вбиває зара-

4 Заревіла престраменна буря, шумить під небесами, носиться по полю, упирається у ліс, преть його, мов з місия хоче його спихнути і зомняти овсі; гілляки тріщать, ламаються, падають... [...]. Нi, — кричить Денис, - мені бог смерть дасть... мене грім уб'є... Я злодій!... Я прикидався добрим, на других пеню зводив, тебе мав зарізати, щоб ти про лавку у селі не розказав... тепер кажи! Ось-ось мене бог вб’є; розкажи усім, який я. Див.: Г. КвіткаОснов 'яненко, Перекотиполе, [в:] Його ж, Повісті та оповідання. Драматичні твори, упоряд. і прим. Н.О.Ішиноё, вступ. ст. О. І.Гончара, ред. тому О. І. Гончар, Київ 1982, с. 213.

${ }^{5}$ Над ним і буря казилася, $і$ дощ лопотів, і грім тарабанив - але Федір нічого вже не боявся. Див.: О. Сомів, Київські відьми, [в:] Огненний змій: Фантастичні твори украйнських письменників ХІХ сторіччя, упоряд. Ю. В и н н и ч у к, Київ 1990, с. 57.

${ }^{6}$ Хурделиия тим часом розгулюється дедалі сильніше, вона реве і пригинає все на свому иляху, крутиться $і$ летить вузькими вуличками села, затихаючи десь у безконечних просторах снігових полів. Див.: В. Росковшенко, Орендатор, [в:] Ю. Винн и чук, Чорт зна щсо, Львів 2004, c. 311.

${ }^{7}$ Нарешті однієї ночі, коли на небі гуркотіла страшна гроза, прилетіла на дах його будинку величезна сова й завила так, що й грім не заглушив зловісного ії голосу. Тієї ночі нечестивий пан пропав, а чорт, прилетівщи до нього, ніби як сова, забрав його душу до пекла. Див.: П. Куліш, Огненний змій, [в:] Огненний змій: Фантастичні твори украйнських письменників ХIX сторіччя, с. 132.

8 У ту добу була страшенна буря, так од тієї хати згоріла більша половина села. Див.: О. Стороженко, Марко Проклятий, [в:] Його ж, Закоханий чорт. Історико-фантастичні повісті та оповідання, Київ 2001, с. 256.

${ }_{9}^{9}$ Реве та стогне Дніпр широкий, / Сердитий вітер завива, / Додолу верби гне високі, / Горами хвилю підійма. Див.: Т. Ш е вче н ко, Причинна, [в:] Йо го ж, Кобзар, вступ. стаття О. Гон ч ара, прим. Л.Ф.Кодацькоӥ, іл. худож. О.Данчен ка, Київ 1984, с. 15.

${ }_{10}$ Ватагами ходили хмари; / Між ними молодик блукав; / Вітри в очеретах бурхали, / I Псьол стогнав і клеткотав. Див.: Л. Боров и ков ськ и й, Молодиия, [в:] Украӥнські поетиромантики: поетичні твори, упоряд. і приміт. М. Л. Гончарука; вступ. ст. М.Т. Яценка, Київ 1987, с. 38.

${ }^{11}$ Надворі вже зачиналася страшна боротьба природи, грізна, гуляща літня буря, так дуже подібна до боротьби почувань, до кипучої грізної боротьби пристрастей у молодому сериі. Див.: І. Я. Франко, Петрії і Довбушуки, [в:] Його ж, Повісті, Львів 1990, с. 269.

${ }^{12}$ Великі зашпори заганяло життя у серие Прісьиі, страшким морозом кувало їи душу! Як мучена, сиділа тепер вона на полу, і не хотілося ї̈ дивитись ні на щзо, не хотілося дихати; спустивши очі, вона важко зітхала... Буря вила й одкликалася болістю па ї̈ душі, на кістках, на сериі. Див.: П. Ми рн и й, Повія, [в:] Й о го ж , Твори, в 5 томах, Київ 1954, т. 3, с. 14. 
ди ідеї “загірної комуни” рідну матір у пророчій новелі конгеніального прозаїка доби "Розстріляного Відродження" Миколи Хвильового Я (Романтика) $(1924)^{13}$. I, урешті, одне із сучасних художніх утілень мотиву бурі в оповіданні письменниці-сімдесятниці Катерини Мотрич Горобина ніч, у якому героєві доводиться в буряну ніч терміново довезти вагітну жінку до віддаленої лікарні. Буря в карпатських лісах стає паралеллю до терпіння лісникової жінки, у якої почалися складні пологи, сум'яття думок її позірно грубого чоловіка, урешті, до суперечних відчуттів гості лісникової хати - молодої журналістки ${ }^{14}$.

Василь Ткачук двічі у своїй творчості побудував сюжет, звертаючись до мотиву природного лиха. У новелі Повінь жителі села тонуть у хвилях розбурханої ріки. Заголовна повінь, що “не пардонує”, ставить героїв у межову ситуацію, викликає жах, відчай, поглинає людські життя. У Бурі шалений гірський буревій стає свідком крайніх людських пристрастей - викриття зради в коханні, що для зрадженого гірше смерті.

Окрім того, до мотиву бурі поодинокими мазками звертається письменник і в інших своїх новелах. Ткачукові герої усвідомлюють силу і міць буревію, що постійно функціонує в їхньому світосприйнятті. Так, малий Шкільник з однойменної новели, хоча “ще малий”, ідучи до школи, ,пускав довгі кроки, наче бузьок, а нагнувся вперід, гей тополя від бурi $i^{15 " 16}$. У Родимому ворожка радить матері оберігати молодшого сина ,аби вважав, як буде буря віяти, то аби верха держався" "17. У новелі Набуток весільна хата, повна розтанцьованих весільників, порівнюється до грізного передгроззя: „От так було, як коли в хмарі вариться-варкотить перед громами та зливою...”18.

Традиційно в уяві Ткачукових героїв буря - неприборкана стихія, як правило, персоніфікована. Так, у новелі Колядник „...Буря горланила. Пригорщами кидала сніжком у вікна, то дужими плечима знімала хоромні двері зі завіс, то вплелась у чорний дах, аж тріскотів, аж холітався. Аж лячно"19. Вона ототожнюється з дикою бестією, яка "прожирала", "метала, в безвість" людський “мелодійний шепіт", “тиху молитву"20. У згадуваній вище новелі Повінь потужний водяний вал, що поглинає все на своїй дорозі, порівнюється до шаленого мчання грозових хмар: „Інколи притаїться й суне-суне, немов хмара, гнана бурею”21.

Мотив бурі в Ткачукових новелах використовується не лише з метою зображення сили стихійного лиха, але щоб віддзеркалити крайні людські емоції, що міццю прирівнюються до нищівної сили буревію. Так, у новелі Мосяжні серия старий самітний Олекса, що втратив дружину й сина, не міг віднайти душевного спокою. Інколи він „замовкав, як той ясень, [...], та інколи лютився, як буря

${ }^{13}$...Іила гроза. Десь пробивалися досвітні плями. Тихо вмирав місящь у пронизаному зеніті. 3 заходу насувалися хмари. Див.: М. Х в иль о в ий, Я (Романтика), [в:] Й ого ж, Твори, у 2 томах, Київ 1990, т. 1: Поезія. Оповідання. Новели. Повісті, упоряд. М. Г. Жули н ського, П. І. Майдаченка, передм. М.Г.Жулинського, с. 339.

14 Завивав ліс, і від того ставало тривожно й неспокійно. Вилущувало небо громи, й вони губилися поміж дерев довгим відлунням. Див.: К. Мотрич, Горобина ніч, [в:] Ї̈̈̈ ж, Соняхи. Новели, вступ. М. О лійни ка, Київ 1978, с. 85.

${ }^{15}$ Слово "буря" в цитованих фрагментах новел В. Ткачука виділяємо курсивом.

${ }_{16}$ В. Ткачук, Шкільник, [в:] Його ж, Сині чічки. Новели, передм. Х. Синітович, Івано-Франківськ, 2013, с. 18.

${ }^{17}$ В. Ткачук, Родимий, [в:] Його ж, Сині чічки..., с. 20.

${ }^{18}$ Там само, с. 79.

${ }^{19}$ В. Ткачук, Колядник, [в:] Його ж, Сині чічки..., с. 41.

${ }^{20}$ Там само.

${ }^{21}$ В. Ткачук, Повінь, [в:] Його ж, Сині чічки..., с. 58. 
рвала широкі листи й метала ними куди оком стякнеш, так і Олекса: ... - Бийси по камінню"22. Герої новели Аби не дати, розлючені перспективою беззаконного відбирання землі, що мала перейти в чужу власність, „розговорились, наче громи восени, як дуби проти бурі"23. I, урешті, героїня новели Діточа земля, дізнавшись, що чоловік продав землю - дитяче віно, бажає йому зла, замовляючи бурю: „Будемо молоти тучі, грому на тебе”"24.

Особливо промовистий мотив бурі в новелі За штрикою, що поруч Бурі належить до найкращих зразків Ткачукової малої прози. Тут так само, як і в кількох згаданих вище новелах покутського прозаїка, мотив бурі використовується 3 метою показати крайні емоції жінки-матері, яка втратила сина-дезертира. Надворі - літня спека. Однак, коли стара мати розуміє, що іiї сина вбили у схованці в житах, іï крик і розпач порівнюється з бурею. „Село слухає-слухає: То не буря, запутавшись у густі смереки, виє-вийойкує, то за штрикою Михайлиха стогне, плаче...”25. Цікаво, що В. Ткачук застосував тут сповнений особливою експресією та можливостями емоціонального впливу на читача заперечний паралелізм, що є одним з прийомів т. зв. поетичного синтаксису ${ }^{26}$.

У новелі Буря, що є предметом цього дослідження, доволі традиційний сюжет зі збереженням домінанти новелістичного жанру - одноподієвості. Причому, як підкреслює сучасна дослідниця Христина Федор, „письменника цікавить не зовнішня подієвість, а психологічний внутрішній стан людини у певні моменти життя"27. Іще в 1940-му році авторитетний тогочасний критик Михайло Рудницький зазначав, що новеліст „рідко коли береться за сюжет, який ішов би від зав'язки через наростання конфлікту до будь-якої розв'язки. Він вибирає тільки один момент, одну картину, одне переживання і навіть не зображує їх, а передає, виражає настрій”28. Таким “одним моментом" у новелі Буря є раптове викриття подружньої зради і трагічні наслідки цього. Молодий герой, підозрюючи свою кохану в зраді, вбігає розлючений у хату з наміром з'ясувати правду. Коли жінка підтверджує його підозри, гуцул востаннє сідає за стіл на “прощальну трапезу”, щоб згодом вибігти надвір з наміром убити жінчиного полю-

${ }^{22}$ В. Ткачук, Мосяжні серия, [в:] Його ж, Сині чічки..., с. 83.

${ }^{23}$ В. Ткачук, Аби не дати, [в:] Його ж, Сині чічки..., с. 124.

${ }^{24}$ В. Тккчук, Діточа земля, [в:] Його ж, Сині чічки.., с. 103.

${ }^{25}$ Там само, с. 57.

${ }^{26}$ Окрім прямого паралелізму, дослідники виділяють т. зв. заперечний паралелізм (“сслов’янська антитеза"), побудований на основі заперечного зіставлення. Відомий іще з народної творчості, наприклад у таких народних думах, як: Втеча трьох братів із города Озова, з турецької неволі („То вже не сизі орли заклекотали, / А то ж турки-яничари бідних двох козаків та коло могили хапали / Постріляли їх і порубали, [...]”) чи Бідна вдова і три сини („То не сива зозуля кувала, / Не дрібна птиця щебетала, / Не у борі сосна шуміла, / То бідна вдова у своєму домі / 3 своїми дітьми гомоніла [...]"). Див.: Українські народні думи та історичні пісні. Збірник, с. 64, 105. Стилізуючи народну пісню, Іван Франко також використав прийом заперечного паралелізму в одному зі своїх поетичних шедеврів Зів'ялого листя (1896) - Як почуєш вночі край свойого вікна („То не та сирота, що без мами блука, / Не голодний жебрак, моя зірко. / Се розпука моя, невтишима тоска, / Се любов моя плаче так гірко"). Див.: І. Я. Франко, Зів'яле листя, [в:] Його ж, Зібрання твоpiв, у 50-и томах, Київ 1976 р., т. 2, с. 151.

Синтаксичний прийом заперечного паралелізму застосував В. Ткачук не лише в новелі За штрикою, але й у творі Бог гнівавбиси, у якому селянин Григор, вражений безпідставним ув'язненням молодого односельчанина, “схопився” й “одним духом” побіг захищати у суді звинуваченого („То не дуб учахнувся, не стіна влупалась, то Григор так пішов”). Див.: В. Ткачук, Бог гнівавбиси, [в:] Й о го ж, Сині чічки ..., с. 73.

27 Див.: Х. Федор, Василь Ткачук в західноукраїнському літературному та культурному проиесі початку ХХ століття ..., с. 270.

${ }^{28}$ Див.: М. Рудницький, Василь Ткачук „Весна”, [в:] „Література і мистецтво” 1940, № 1, с. 14. 
бовника. Імовірно, на заваді стане йому смерть у лабетах буревію, що супроводжує хід подій у творі. Гуцульська обстановка дії, мотив нездійсненного кохання споріднює новелу В. Ткачука з найславнішою українською повістю про незбуту любов гуцулів - Тінями забутих предків (1911) Михайла Коцюбинського. Імена Ткачукових героїв - Іванчік та Дзвінка навіюють думку про ремінісцентні образи нещасного Івана Палійчука із щойно згаданого твору фундатора імпресіонізму в українській літературі та полюбовниці-зрадниці Дзвінчучки, причетної до смерті легендарного карпатського опришка - Олекси Довбуша ${ }^{29}$.

Композиційним стрижнем твору є образ бурі, що обрамлює твір. Лаконічна новела починається і завершується грозою, що не вщухає. Уже перші рядки твору: „На груні співанка розгойдувала ліси, аж коріння хрупотіло. Збудило тишу на полонині. Лише Прут не давався заглушити [...]”зо віщують лихо, уводять читача в настрій неспокою, ущеплюючи передчуття якоїсь невловимої тривоги. Заключні акорди новели: „Та Іванчіка обняла сердита буря й не пустила, аби не вертався"з1 підтверджують прогнозований зловіщим зачином твору трагічний фінал розв'язки конфлікту. Таким чином, заголовна буря, відкриваючи собою твір, задає емоційний тон і водночас виступає в ролі емоційно значущого фіналу, символічно узагальнюючи й прогнозуючи наслідки вчинків і духовних переживань героїв.

Мотив бурі наявний у новелі на двох взаємопов'язаних рівнях: по-перше, як стихійне лихо - природне явище, що $є$ тлом для драматичних подій, подруге, як уособлення крайніх емоцій людини, яка поставлена в межову, а то й глуху ситауцію. Дворівневість реалізації мотиву бурі у творі В. Ткачука своїм джерелом сягає полісемії слова, що означає: по-перше, негоду, що супроводжується сильним навальним вітром $з$ дощем, грозою, а взимку зі снігом; інші назви - борвій, хуртовина, вітряниия, буревій та ін.; по-друге, глибоке хвилювання, сильні душевні переживання; інші назви - гроза, завірюха та ін. Окрім указаних вище значень слова “буря”, дослідники виділяють ще два: 'бурхливі події, що відбуваються в суспільстві', а також 'надзвичайно сильний вияв чого-небудь' ${ }^{32}$.

Образ бурі як природної стихії відображений у творі дуже пластично. Поміж художніх засобів, що їх викорстовує В. Ткачук з метою змалювання картини буревію, домінанту роль відіграють порівняльні конструкції, що апелюють до органів чуття реципієнта, створюють образність мови за допомогою пробудження читацької уяви. Це, головно, конструкції з порівняльними сполучника-

${ }^{29}$ У народі романтизують смерть Олекси Довбуша, пов'язуючи ії з черговою полюбовницею опришка - Дзвінкою. Імовірно, Довбуша застрелив у серпні 1745 року розгніваний Степан Дзвінчук - селянин, який раніше повернувся додому і, побачивши жінку з Довбушем, схопився за пістолю. Дзвінка згадується в народній пісні про Довбуша Ой попід гай зелененький („Ой попід гай зелененький / Ходить Довбуш молоденький / [...] / На топір ся підпирає / Та й на хлопців закликає: / «Ой, ви хлопці, ба й молодці, / Набивайте по стрільбочці / I держіться при купочці, / Бо я їду до милої, / Ба й до жінки Дзвінкової»”). Див.: Українські народні думи та історичні пісні. Збірник, с. 176-177.

Історію з коханкою Довбуша обіграли і в кінофільмі Олекса Довбуши (1959), причому там Довбушева полюбовниця - Марічка. Через кілька років Роман Федорів написав роман у легендах Жбан вина (1968), у якому зображено життя і смерть Довбуша. Один з епізодів повісті присвячений зрадливій Двінчучці.

${ }^{30}$ В. Ткачук, Буря, [в:] Його ж, Сині чічки..., с. 162.

${ }^{31}$ Там само, с. 164

32 Див.: напр., Словник синонімів украйнської мови, у 2-х томах, упоряд. А. А. Бурячок, Г. М. Гнатюк, С. І. Головащук, Київ 2001, т. 1, с. 107-108. 
Буря Василя Ткачука (про забуту новелу „загубленого таланту”)

ми “наче” (Прут „наче п’яний легінь гупався в тверді плечі скал”з3; верхи „білими поясами-плаями вперезані, наче позакурювали люльки” (163); „смереки збивались докупи, наче кудлаті вівіці”), “ніби” (буря „вискочила на шпиці, ніби їще розглянутись хотіла”), “гей”34 (, [...] піна йшла, гей скаженій собаці з рота"35).

Поміж порівняльних конструкцій виділяються також порівняння 3 підсилювальною часткою “аж” (Прут „скреготав, аж піна йшла”“36).

Окрім того, новеліст використовує засіб персоніфікації. Бурхливий Прут порівнюється до “П’яного легеня”, що “не дався заглушити”, “гупався” i “скреготав”37. Розгойдані під час бурі гірські верхи — це „моцаки-легіні, косиками-смереками закосичені, білими поясами-плаями вперезані”, що курили люльки і ,пахкали молочними димами”з8. Буря — це моцарка, що „в міжгір”і випростовувала рамена і моцувалася”, ялиці — „до вікон пригиналися й приглядалися”, яруги — „приставали та наслухали [...]”39; буря ,з міжгір вискочила”, „пустилась стрімголов у звори”, „летіла”, „метала сосонками”, „скочувала великі камені”, „Іванчіка обняла”, „не пустила”40 та ін.

Заголовна буря у Ткачуковому творі — це не лише природне явище. Це також крайні емоції, що віддзеркалюють споконвічні пристасті між чоловіком і жінкою. Душевно понівечений герой вирішує “на відході” попоїсти, „як чесні, як величні газди, [...], що бурі в їх хаті ніколи не було"41.

Для яскравішого увиразнення драматизму подій у новелі використовується прийом психологічного паралелізму — контрастного зіставлення або протиставлення картин природи 3 емоційним станом людини. Природа акомпанує людським переживанням, причому акомпанемент може бути побудований на консонансах (пейзаж-консонанс) або на дисонансах (пейзаж-дисонанс) $)^{42}$. У Бурі В.Ткачука переважає перший тип паралелізму. Опис бурі, що відкриває й завершує твір, цілком відповідає душевній бурі головного героя. Більше того, коли ошалілий від передчуття жінчиної зради Іванчік ,влетів до хати” в супроводі бурі, оживлюються й неживі предмети — „вікна ойкнули, сволоки хрупнули, земля промовила"43. Водночас за принципами контрасту зображена реакція Іванчікової жінки - винуватиці. Коли від скоєного зла в супроводі бурі навіть мертві предмети оживають, жива людина кам'яніє: „А Дзвінка стала, як крига леду”. Буря „горланить”, Іванчік ,заввихнувся” і ,луснув кулаком у сволок”, тоді як Дзвінка „притихла”, „очі опустила”44.

Паралелізм реалізується традиційно для В. Ткачука за допомогою порівняльних конструкцій зі сполучним словом “як” (,стала, як крига леду”), “наче” (,притихла наче перед зривом вихру”), “мов” (,мов крила, опустила руки”; „байбарак злетів, мов листок”), а також з часткою “аж” (,заввихнувся, аж защіпки трісли, аж байбарак злетів”).

${ }^{33}$ В. Ткачук, Буря, [в:] Його ж, Сині чічки..., с. 162.

${ }^{34}$ Гей (гейби) - це діалектні сполучники, що $є$ відбиттям живорозмовного мовлення українських говорів Карпатського регіону.

${ }^{35}$ В. Ткачук, Буря, [в:] Його ж, Сині чічки..., с. 162.

${ }^{36}$ Там само.

${ }^{37}$ Там само.

${ }^{38}$ Там само, с. 163.

${ }^{39}$ Там само.

${ }^{40}$ Там само, с. 164.

${ }^{41}$ Там само, с. 163.

42 Див. детальніше на цю тему: О. Галич, В. Назарець, Є. Васильєв, Теорія літератури, за наук. ред. О. Га л и ч а, Київ 2001, с. 159.

${ }^{43}$ В. Тк ачук, Буря, [в:] Його ж, Сині чічки..., с. 162.

${ }^{44}$ Там само. 
Буря у В. Ткачука віщує смерть. Іванчікова вечеря "на відході" нагадує “прощальну трапезу”, сприймається як своєрідний реквієм за живою ще людиною. Герой, який утратив сенс життя, не боїться смерті. Він покидає хату нібито з наміром убити жінчиного полюбовника, але, вибігаючи в розпал буряної стихії, прирікає себе на певну смерть, на що посередньо вказують завершальні рядки новели: „Іванчіка обняла сердита буря й не пустила, аби не вертався. $[\ldots] . .$. Відтак зник у темних крилах заверюхи...”45. На трагічний фінал зрадженої Іванчікової любові вказує й одна з віртуозних метафор, характерних для поетики новел Ткачука: „Блискавиці гадюками вилися кругом нього. А він кинув їм своє серце, аби посікли, бо й так трісло на дві половини"46.

На розтрощене в друзки життя Іванчіка після викриття зради вказує й інше метафоричне висловлювання: „Іванчік був не одну плиту підважив та підніс, та цієї, що впала на його груди, не міг й рушити" 47 . У центрі вищевказаних метафоричних висловлювань фразеологічні сполучення: „кинув своє серце”, „серце трісло”, „плита впала на груди”. Окрім того, В. Ткачук використовує інші фразеологічні сполучення для увиразнення емоцій героя. Іванчік зверається до Дзвінки з попередженням „не каламутити життя”, „не бовтати”, „щоб їх люди не носили нас на зубах", щоб їх “Бог не вимазав з книги”"48. Герой рве “на биндочки” “панську” одежу жінки, примовляючи: „Не меш на поругу ходити! Не меш рід паскудити, гуцульську ношу поганити”"49.

Василь Ткачук - невиправний любитель життя, що парадоксально передчасно його поглинуло, майстерно відобразив найболючіші пристрасті й тонкощі чоловічо-жіночих відносин. Незважаючи на мотив зради, його героїня не викликає ненависті й погорди. Читач співчуває їй, розуміючи, що вона теж жертва - убивчої пристрасті. Сама Дзвінка усвідомлює власну моральну неправоту, іменує себе "пустим насіннячком", “гнилим коріннячком”, звертається до чоловіка 3 проханням покарати іiі: „Бий мене, бий зрадницю" ". Іванчік не може визначитися, як йому ставитись до невірної жінки. У його голові клубочуться суперечні відчуття. Він безжально картає iii, уживаючи образливі слова: „Стямся, лєцта суко”, „ховзка Дзвінко”, висловлює прокльони: „Бодай тобі, Дзвінко, води зіграли, як будеш ріку переходити, а най тобі вогні очі випалять, а громи заглушать..." 51 . I водночас герой звертається до жінки 3 любов'ю, ніби шукаючи порятунку для їхнього зганьбленого кохання: „Дзвінко, чічко моя! Ясочко пишна та любезна!”, „Дзвінко, а це чіє, любко?”52. В образі Дзвінки відображена любов автора до Жінки як такої. Прикметно, що В. Ткачук - майстер жіночих постатей, поміж яких за поодинокими винятками вимальовуються образи закоханої нареченої, турботливої дружини, самовідданої матері та ін., що є іпостасями суцільного образу доброї і відважної Жінки-берегині.

Буря в однойменній новелі Василя Ткачука - це символ неприборканої сили, що несе із собою знищення, руїну, смерть і водночас має очисний характер, дає відвагу Дзвінці зізнатись чоловікові в забороненій любові

\footnotetext{
${ }^{45}$ Там само, c. 164.

46 Там само.

${ }^{47}$ Там само, с. 62.

${ }^{48}$ Там само.

${ }^{49}$ Там само, с. 163.

${ }^{50}$ Там само, с. 162

${ }^{51}$ Там само, с. 163.

${ }^{52}$ Там само.
} 
Буря Василя Ткачука (про забуту новелу „загубленого таланту”)

(„,Бо я його любити мушу [...]”53). У iї супроводі Іванчік прискорює рішення покинути дружину, шукати справедливості, обіцяючи помститися “чужій кровці”, готовий на смерть. Під час бурі розкрилася таємниця зради. Після бурі оновиться природа, щезне і брехня.

Отож, мав рацію Олександр Олесь, що так само, як і Василь Ткачук, проникливо писав і про любов, і про природу, коли укладав відомі поетичні рядки: „Гроза пройшла... зітхнули трави, / Квітки голівки підняли, [...] / Сміються знову трави, квіти... / А сльози ще тремтять на них" ${ }^{54}$.

\footnotetext{
${ }^{53}$ Там само, с. 162.

${ }^{54}$ О. Олесь, Гроза пройшла... зітхнули трави, [в:] Його ж, Чари ночі. Лірика, Київ 1989, с. 22.
} 